\title{
PENGANTAR DAN SEJARAH PERKEMBANGAN ILMU HADIS
}

\section{A. Pendahuluan}

Alquran sebagai kalâm Allah (firman Allah) mencakup segala aspek persoalan kehidupan manusia dalam berinteraksi dengan pencipta-Nya, sesama manusia dan alam semesta yang merupakan persoalan mendasar dalam setiap kehidupan manusia. ${ }^{1}$ Alquran sebagai kitab suci umat Islam sangat kaya dengan pesan-pesan yang mengandung nilai-nilai pendidikan. ${ }^{2}$

Sedangkan Hadits bermakna seluruh sikap, perkataan dan perbuatan Rasulullah SAW dalam menerapkan ajaran Islam serta mengembangkan kehidupan umat manusia yang benar-benar membawa kepada kerahmatan bagi semua alam, termasuk manusia dalam mengaktualisasikan diri dan kehidupannya secara utuh dan bertanggung jawab bagi keselamatan dalam kehidupannya. Kedudukan al-Sunnah dalam kehidupan dan pemikiran Islam sangat penting, karena di samping memperkuat dan memperjelas berbagai persoalan dalam Alquran, juga banyak memberikan dasar pemikiran yang lebih kongkret mengenai penerapan berbagai aktivitas yang mesti dikembangkan dalam kerangka hidup dan kehidupan umat manusia.

Sebelum berbicara tentang pengertian, status, dan perkembangan ilmu hadis, terlebih dahulu akan dijelaskan secara singkat, kapan ilmu hadis muncul. Ilmu hadis muncul sejak masa Rasulullah SAW dan perhatian para sahabat terhadap hadis atau sunnah sangat besar. Demikian juga perhatian generasi berikutnya seperti Tabi'in, 'Tabi' Tabi'in, dan generasi setelah Tabi'in. Mereka memelihara hadis dengan cara menghapal, mengingat, bermudzakarah, menulis, menghimpun, dan mengodifikasikannya ke dalam kitab-kitab hadis yang tidak terhitung jumlahnya. Akan tetapi, di samping gerakan pembinaan hadis tersebut, timbul pula kelompok minoritas atau secara individual berdusta membuat hadis yang disebut dengan hadis mawdh $\hat{u}^{\prime}$

1 Muh. Haris Zubaidillah, "Epistemological Views of Islamic Education Philosophy as a Islamic Education Basis," Al Qalam: Jurnal Ilmiah Keagamaan dan Kemasyarakatan 12, no. 1 (2018): h. 3.

${ }^{2}$ Muh. Haris Zubaidillah, "Nilai-Nilai Pendidikan Adversity Quotient pada Cerita Nabi Musa dalam Alquran," Al Qalam: Jurnal Ilmiah Keagamaan dan Kemasyarakatan 11, no. 24 (2017): h. 22. 
(hadis palsu). Maksudnya menyandarkan sesuatu yang bukan dari Nabi, kemudian dikatakan dari Nabi SAW.

Kondisi hadis pada masa perkembangan sebelum pengodifikasian dan filterisasi pernah mengalami kesimpang siuran di tengah jalan, sekalipun hanya minoritas saja. Oleh karena itu, para ulama bangkit mengadakan riset hadis-hadis yang beredar dan meletakkan dasar kaidah-kaidah atau peraturan-peraturan yang ketat bagi seorang yang meriwayatkan hadis yang nantinya ilmu ini disebut ilmu hadis. Meskipun makalah ini tidak bisa memuat hal-hal yang berkaitan dengan pengantar dan sejarah perkembangan ilmu hadis secara menyeluruh, tapi paling tidak makalah ini cukup mampu untuk memperkenalkan kita bagaimana sejarah perkembangan ilmu hadis.

Berdasarkan permasalahan di atas dalam makalah ini kami berusaha mencoba menjelaskan pengertian ilmu hadis dan bagaimana sejarah perkembangan ilmu hadis.

\section{B. Pengertian Ilmu Hadis}

Dari segi bahasa ilmu hadis terdiri dari dua kata, yaitu ilmu dan hadis. Secara sederhana ilmu artinya pengetahuan, knowledge,dan science. Sedangkan hadis artinya segala sesuatu yang disandarkan kepada Nabi Muhammad SAW, baik dari perkataan, perbuatan, maupun persetujuan. Para ulama ahli hadis banyak yang memberikan definisi ilmu hadis, di antaranya Ibnu Hajar Al-Asqalani:

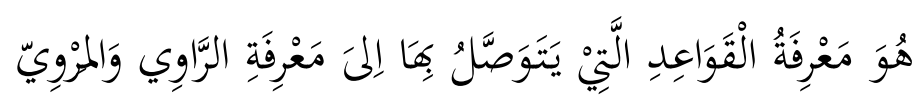

Adalah mengetahui kaidab-kaidah yang dijadikan sambungan untuk mengetahui (keadaan) perawi dan yang diriwayatkan.

Atau:

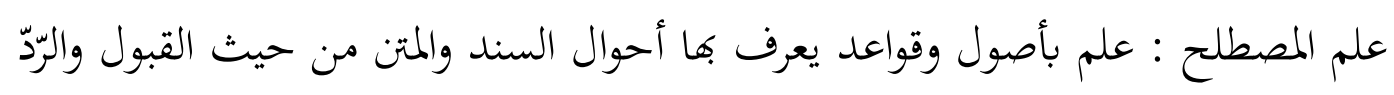

Ilmu yang mempelajari tentang keterangan suatu hal yang dengan hal itu kita dapat mengetahui bahwa hadis itu diterima atau tidak. ${ }^{3}$

Atau definisi yang lebih ringkas:

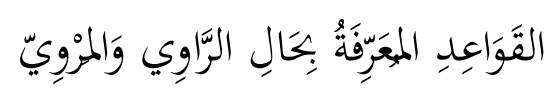

${ }^{3}$ Mahmud al-Thahhan, Taisir Musthalahal al-Hadits (Beirut: Dar ats-Tsaqafah al-Islamiyah, t.t.), h. 15. 


\section{Kaidah-kaidah yang mengetabui keadaan perawi dan yang diriwayatkannya. ${ }^{4}$}

Dari definisi di atas dapat dijelaskan bahwa ilmu hadis adalah ilmu yang membicarakan tentang keadaan atau sifat para perawi dan yang diriwayatkan. Perawi adalah orang-orang yang membawa, menerima, dan menyampaikan berita dari Nabi, yaitu mereka yang ada dalam sanad suatu hadis.

Bagaimana sifat-sifat mereka, apakah bertemu langsung dengan pembawa berita atau tidak, bagaimana sifat kejujuran dan keadilan mereka, dan bagaimana daya ingat mereka, apakah sangat kuat atau lemah. Sedangkan maksud yang diriwayatkan (marwî) terkadang guru-guru perawi yang membawa berita dalam sanad suatu hadis atau isi berita (matan) yang diriwayatkan, apakah terjadi keganjilan jika dibandingkan dengan sanad atau matan perawi yang lebih kredibel (tsiqah). Dengan mengetahui hal tersebut, dapat diketahui mana hadis yang shahih dan yang tidak shahih. Ilmu yang berbicara tentang hal tersebut disebut ilmu hadis.

Ilmu hadis ini kemudian terbagi menjadi dua macam, yaitu Ilmu Hadis Riwayâh dan Ilmu Hadis Dirâyah.

\section{Sejarah Perkembangan Ilmu Hadis}

Sesuai dengan perkembangan hadis, ilmu hadis selalu mengiringinya sejak masa Rasulullah S.A.W, sekalipun belum dinyatakan sebagai ilmu secara eksplisit. Ilmu hadis muncul bersamaan dengan mulainya periwayatan hadis yang disertai dengan tingginya perhatian dan selektivitas sahabat dalam menerima riwayat yang sampai kepada mereka. Dengan cara yang sangat sederhana, ilmu hadis berkembang sedemikian rupa seiring dengan berkembangnya masalah yang dihadapi. Pada masa Nabi SAW masih hidup di tengah-tengah sahabat, hadis tidak ada persoalan karena jika menghadapi suatu masalah atau skeptis dalam suatu masalah mereka langsung bertemu dengan beliau untuk mengecek kebenarannya atau menemui sahabat lain yang dapat dipercaya untuk mengonfirmasinya. Setelah itu, barulah mereka menerima dan mengamalkan hadis tersebut.

\footnotetext{
${ }^{4}$ Ajaj al-Khathib, Ushûl Al-Hadìts, t.t., h. 33.
} 
Sekalipun pada masa Nabi tidak dinyatakan adanya ilmu hadis, tetapi para peneliti hadis memperhatikan adanya dasar-dasar dalam Alquran dan hadis Rasulullah S.A.W. Misalnya firman Allah S.W.T dalam Q.S. Al-Hujurat/49: 6.



Hai orang-orang yang beriman, jika datang kepadamu orang fasik membawa suatu berita, maka periksalah dengan teliti, agar kamu tidak menimpakan suatu musibah kepada suatu kaum tanpa mengetahui keadaannya yang menyebabkan kamu menyesal atas perbuatanmu itu.

Demikian juga dalam Q.S. Al-Baqarah/2: 282.

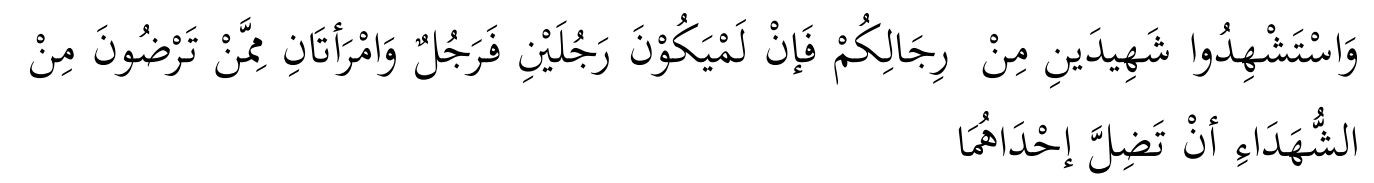

Dan persaksikanlah dengan dua orang saksi dari orang-orang lelaki di antara. Jika tidak ada dua orang lelaki, maka (boleh) seorang lelaki dan dua orang perempuan dari saksi-saksi yang kamu ridhai, supaya jike seorang lupa maka seorang lagi mengingatkannya.

Ayat-ayat di atas berarti perintah memeriksa, meneliti, dan mengkaji berita yang datang dibawa seorang fasik yang tidak adil. Tidak semua berita yang dibawa seseorang dapat diterima sebelum diperiksa siapa pembawanya dan apa isi berita tersebut. Jika pembawanya orang yang jujur, adil, dan dapat dipercaya maka diterima. Akan tetapi sebaliknya, jika pembawa berita itu orang fasik, tidak objektif, pembohong dan lainlain, maka tidak diterima karena akan menimpakan musibah terhadap orang lain yang menyebabkan penyesalan dan merugikan.

Setelah Rasulullah SAW wafat, para sahabat sangat berhati-hati dalam meriwayatkan hadis karena konsentrasi mereka kepada Alquran yang baru dikodifikasi pada masa Abu Bakar tahap awal, khalifah Abu Bakar tidak mau menerima suatu hadis yang disampaikan oleh seseorang, kecuali orang tersebut mampu mendatangkan saksi untuk memastikan kebenaran riwayat yang disampaikannya. Dan masa Utsman tahap kedua, masa ini terkenal dengan masa taqlîl ar-riwayâh (pembatasan periwayatan), para sahabat tidak meriwayatkan hadis kecuali disertai dengan saksi dan bersumpah bahwa hadis yang ia riwayatkan benar-benar dari Rasulullah SAW. Para sahabat merupakan rujukan yang utama bagi dasar ilmu riwayah hadis. Yakni, karena hadis pada masa 
Rasulullah SAW merupakan suatu ilmu yang didengar dan didapatkan langsung dari beliau, maka setelah beliau wafat hadis di sampaikan oleh para sahabat kepada generasi berikutnya dengan penuh semangat dan perhatian sesuai dengan daya hafal mereka masing-masing. Para sahabat juga telah meletakkan pedoman periwayatan hadis untuk memastikan keabsahan suatu hadis. Mereka juga berbicara tentang para rijal-nya, hal ini mereka tempuh supaya dapat diketahui hadis makbul untuk diamalkan dan hadis yang mardud untuk ditinggalkan. Dan dari sini muncullah mushthalah al-hadits.Pada masa awal Islam belum diperlukan sanad dalam periwayatan hadis karena orangnya masih jujur-jujur dan saling mempercayai satu dengan yang lain. Akan tetapi, setelah terjadinya konflik fisik (fitnah) antar elite politik, yaitu antara pendukung Ali dan Mu'awiyah dan umat berpecah menjadi beberapa sekte; Syi'ah, Khawarij, dan Jumhur Muslimin. Setelah itu mulailah terjadi pemalsuan hadis (hadis mawdhû') dari masingmasing sekte dalam rangka mencari dukungan politik dari masa yang lebih luas. Melihat kondisi seperti hal di atas para ulama bangkit membendung hadis dari pemalsuan dengan berbagai cara, di antaranya riblab checking kebenaran hadis dan mempersyaratkan kepada siapa saja yang mengaku mendapat hadis harus disertai dengan sanad. Sebagaimana ungkapan ulama hadis ketika dihadapan suatu periwayatan:



Sebutkan kepada kami para pembawa beritamu. ${ }^{5}$

Ibnu Al-Mubarak berkata:

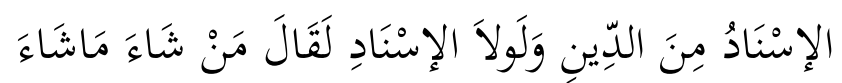

Isnad/sanad bagian dari agama, jikalau tidak ada isnad sunggub sembarang orang akan berkata apa yang dikehendaki. ${ }^{6}$

Keharusan sanad dalam penyertaan periwayatan hadis tidak diterima, tuntutan yang sangat kuat ketika Ibnu Asy-Syihab Az-Zuhri menghimpun hadis dari para ulama di atas lembaran kodifikasi. Pernyataan tersebut menunjukkan bahwa periwayatan hadis tidak di terima, kecuali disertai sanad.

Pada periode Tabi'in, penelitian dan kritik matan semakin berkembang seiring dengan berkembangnya masalah-masalah matan yang para Tabi'in hadapi. Demikian

5 Ahmad Umar Hasyim, As-Sunnah An-Nabawiyyah, t.t., h. 363-364.

6 an-Nawawi, Shabih Muslim bi Syarh An-Nawawi, Juz 1, t.t., h. 103. 
juga dikalangan ulama-ulama hadis selanjutnya. Perkembangan ilmu hadis semakin pesat ketika ahli hadis membicarakan tentang daya ingat para pembawa dan perawi hadis kuat atau tidak (dhâbit), bagaimana metode penerimaan dan penyampaiaan (thammul wa adâ), hadis yang kontra bersifat menghapus (nâsikh dan mansûkh) atau kompromi, kalimat hadis yang sulit dipahami (gharîb al-hadîts), dan lain-lain. Akan tetapi, aktivitas seperti itu dalam perkembangannya baru berjalan secara lisan (syafawî) dari mulut ke mulut dan tidak tertulis.

Ketika pada pertengahan abad kedua Hijriyah sampai abad ketiga Hijriyah, ilmu hadis mulai di tulis dan dikodifikasi dalam bentuk yang sederhana, belum terpisah dari ilmu-ilmu lain, belum berdiri sendiri, masih campur dengan ilmu-ilmu lain atau berbagai buku atau berdiri secara terpisah. Tetapi pada dasarnya, penulisan hadis baru dimulai pada abad kedua Hijriyah. Imam Syafi'i adalah ulama pertama yang mewariskan terori-teori ilmu hadisnya secara tertulis sebagaimana terdapat dalam karyanya. Misalnya ilmu hadis bercampur dengan ilmu ushul fiqih, seperti dalam kitab Ar-Risâlah yang ditulis oleh Asy-Syafi'i, atau campur dengan fiqih seperti kitab Al-Umm. Dan solusi hadis-hadis yang kontra dengan diberi nama Ikhtilâf Al-Hadîts karya Asy-Syafi'i (w. $204 \mathrm{H}$ ). Hanya saja, teori ilmu hadisnya tidak terhimpun dalam pembahasan kitab Ar-Risâlah dan kitab Al-Umm.

Sesuai dengan pesatnya perkembangan kodifikasi hadis yang disebut pada masa kejayaan atau keemasan hadis, yaitu pada abad ketiga Hijriyah, perkembangan penulisan ilmu hadis juga pesat, karena perkembangan keduannya secara beriringan. Namun, penulisan ilmu hadis masih terpisah-pisah, belum menyatu dan menjadi ilmu yang berdiri sendiri, ia masih dalam bentuk bab-bab saja. Mushthafa As-Siba’i mengatakan orang pertama kali menulis ilmu hadis adalah Ali bin Al-Madani, syaikhnya Al-Bukhari, Muslim, dan Tirmidzi. ${ }^{7}$ Dr. Ahmad Umar Hasyim juga menyatakan bahwa orang pertama yang menulis ilmu hadis adalah Ali bin Al-Madani dan permasalahannya sebagaimana yang ditulis oleh Al-Bukhari dan Muslim. ${ }^{8}$ Di antara kitab-kitab ilmu hadis pada abad ini adalah kitab Mukhtalif Al-Hadîts, yaitu Ikhtilâf Al-Hadîts karya Ali bin Al-Madani, dan ta'mîl Mukhtalif Al-Hadîts karya Ibnu Qutaibah (w. 276 H). Kedua

\footnotetext{
7 as-siba'i, as-sunnah, t.t., h. 107.

${ }^{8}$ Hasyim, As-Sunnah An-Nabawiyyah, h. 398.
} 
kitab tersebut ditulis untuk menjawab tantangan dari serangan kelompok teolog yang sedang berkembang pada masa itu, terutama dari golongan Mu'tazilah dan ahli bid'ah.

Di antara ulama ada yang menulis ilmu hadis pada mukadimah bukunya seperti Imam Muslim dalam kitab Shahîh-nya dan At-Tirmidzi pada akhir kitab Jâmi'-nya. Di antara mereka Al-Bukhari menulis tiga Târîkh, yaitu At-Târikh Al-Kabîr, At-Târîkh AlAwsâth dan At-Târikh Ash-Shaghîr, Muslim menulis Thabaqât At-Tâbiin dan Al-Tlal, AtTirmidzi menulis Al-Asmâ' wa Al-Kunâ dan KitâbAt-Tawârikh, dan Muhammad bin Sa'ad menulis Ath-Thabaqât Al-Kubrâ. Dan di antara mereka ada yang menulis secara khusus tentang periwayat yang lemah seperti $A d$-Dhu'afâ' ditulis oleh Al-Bukhari dan Ad-Dhu'afâ' ditulis oleh An-Nasa'i, dan lain-lain.

Banyak sekali kitab-kitab ilmu hadis yang ditulis oleh para ulama abad ke-3 Hijriyah ini, namun buku-buku tersebut belum berdiri sendiri sebagai ilmu hadis, ia hanya terdiri dari bab-bab saja. Perkembangan ilmu hadis mencapai puncak kematangan dan berdiri sendiri pada abad ke-4 $\mathrm{H}$ yang merupakan penggabungan dan penyempurnaan berbagai ilmu yang berkembang pada abad-abad sebelumnya secara terpisah dan berserakan. Al-Qadhi Abu Muhammad Al-Hasan bin Abdurrahman bin Khalad Ar-Ramahurmuzi (w. $360 \mathrm{H}$ ) adalah orang yang pertama kali memunculkan ilmu hadis yang berdiri sendiri dalam karyanya Al-Mubaddits Al-Fâshil bain Ar-Râwî wa Al-Wâî. Akan tetapi, tentunya tidak mencakup keseluruhan permasalahan ilmu, kemudian diikuti oleh Al-Hakim Abu Abdullah An-Naisaburi (w. $405 \mathrm{H}$ ) yang menulis Ma'rifah "ulûm Al-Hadîts tetapi kurang sistematik, Al-Khathib Abu Bakar Al-Baghdadi (w. $364 \mathrm{H}$ ) yang menulis Al-Jâmi li Adâb Asy-Syaikh wa As-Sâmi' dan kemudian diikuti oleh penulis-penulis lain. 
Ringkasan Perkembangan Pembukuan Ilmu Hadis

\begin{tabular}{|c|l|l|}
\hline No. & \multicolumn{1}{|c|}{ Masa } & \multicolumn{1}{|c|}{ Karakteristik } \\
\hline 1. & Masa Nabi Muhammad SAW & Telah ada dasar-dasar ilmu hadis. \\
\hline 2. & Masa Sahabat & $\begin{array}{l}\text { Timbul secara lisan, secara eksplisit. } \\
\text { Telah timbul secara tertulis, tetapi } \\
\text { belum terpisah dengan ilmu lain. }\end{array}$ \\
\hline 3. & Masa Tabi'in & $\begin{array}{l}\text { Ilmu hadis telah timbul secara terpisah } \\
\text { dari ilmu-ilmu lain, tetapi belum } \\
\text { menyatu. }\end{array}$ \\
\hline 5. & $\begin{array}{l}\text { Masa setelah Tabi' Tabi'in } \\
\text { (abad ke-4 H) }\end{array}$ & Berdiri sendiri sebagai ilmu hadis. \\
\hline
\end{tabular}

\section{Faedah Mempelajari Ilmu Hadis}

Banyak sekali faedah dan manfaat yang diperoleh dalam mempelajari ilmu hadis, di antaranya sebagai berikut ${ }^{9}$.

1. Mengetahui istilah-istilah yang disepakati ulama hadis dalam penelitian hadis. Demikian juga dapat mengenal nilai-nilai dan kriteria hadis; mana hadis dan mana yang bukan hadis.

2. Mengetahui kaidah-kaidah yang disepakati para ulama dalam menilai, menyaring (filterasi) dan mengklasifikasi ke dalam beberapa macam, baik dari segi kuantitas maupun kualitas sanad dan matan hadis sehingga dapat menyimpulkan mana hadis yang diterima dan mana hadis yang ditolak.

3. Mengetahui usaha-usaha dan jerih payah yang ditempuh para ulama dalam menerima dan menyampaikan periwayatan hadis, kemudian menghimpun dan mengodifikasi ke dalam berbagai kitab hadis.

4. Mengenal tokoh-tokoh ilmu hadis, baik dirâyah maupun riwâyah yang mempunyai peran penting dalam perkembangan pemeliharaan hadis sebagai sumber syariab Islamiyah sehingga hadis terpelihara dari pemalsuan tangantangan kotor yang tidak bertanggung jawab. Seaindainya terjadi hal tersebut, mereka pun dapat mengungkap dan meluruskan yang sebenarnya.

${ }^{9}$ Nuruddin 'Itr, Manhaj An-Naqd Fii 'Uluum al-Hadis (Bandung: Remaja Rosdakarya, 2012). 
5. Mengetahui hadis yang shabîh, hasan, dha'îf, muttashil, mursal, munqati', mu'dal,

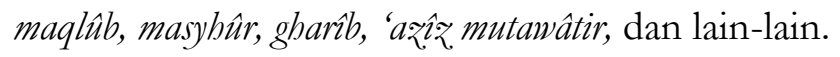

Demikian pentingnya ilmu hadis untuk dipelajari bagi semua umat Islam, terutama bagi yang ingin mempelajari ilmu agama secara dalam sehingga tidak goyah dalam menghadapi goyangan iman yang meragukan otentisitas hadis.

\section{E. Kesimpulan}

Dari segi bahasa ilmu hadis terdiri dari dua kata, yaitu ilmu dan hadis. Secara sederhana ilmu artinya pengetahuan, knowledge, dan science. Atau ilmu hadis adalah ilmu yang mempelajari tentang keterangan suatu hal yang dengan hal itu kita dapat mengetahui bahwa hadis itu diterima atau tidak.

Pada dasarnya, penulisan ilmu hadis baru dimulai sejak abad ke 2 Hijriyah. Sejarah perkembangan dari masa Nabi Muhammad telah ada dasar-dasar ilmu hadis serta pada masa Nabi masih hidup penulisan hadis dilarang keras oleh Nabi, karena khawatir akan bercampur dengan Al-Quran dengan hadis. Pada masa sahabat para sahabat sangat berhati-hati dalam meriwayatkan hadis karena konsentrasi mereka kepada Alquran yang baru dikodifikasi pada masa Abu Bakar tahap awal dan masa Utsman tahap kedua, pada masa sahabat ilmu hadis timbul secara lisan atau secara eksplisit. Pada masa Tabi'in (abad ke-4 H) telah timbul secara tertulis, tetapi belum terpisah dengan ilmu lain. Pada masa Tabi' Tabi'in, imu hadis telah timbul secara terpisah dari ilmu-ilmu lain, tetapi belum menyatu. Sedangkan, pada masa setelah Tabi' Tabi'in ilmu hadis berdiri sendiri sebagai ilmu hadis.

\section{F. Daftar Pustaka}

an-Nawawi. Shabih Muslim bi Syarh An-Nawawi. Juz 1., t.t. as-siba'i. as-sunnah, t.t.

Hasyim, Ahmad Umar. As-Sunnah An-Nabawiyyah, t.t.

'Itr, Nuruddin. Manhaj An-Naqd Fii 'Uluum al-Hadis. Bandung: Remaja Rosdakarya, 2012.

Khathib, Ajaj al-. Ushûl Al-Hadìts, t.t.

Thahhan, Mahmud al-. Taisir Musthalabal al-Hadits. Beirut: Dar ats-Tsaqafah alIslamiyah, t.t.

Zubaidillah, Muh. Haris. "Epistemological Views of Islamic Education Philosophy as a Islamic Education Basis." Al Qalam: Jurnal Ilmiah Keagamaan dan Kemasyarakatan 12, no. 1 (2018): 1-12. 
. "Nilai-Nilai Pendidikan Adversity Quotient pada Cerita Nabi Musa dalam Alquran." Al Qalam: Jurnal Ilmiah Keagamaan dan Kemasyarakatan 11, no. 24 (2017). 